\title{
The extracellular calcium sensing receptor is expressed in mouse mesangial cells and modulates cell proliferation
}

\author{
Jin-Oh Kwak', Jiyeon Kwak ${ }^{2}$, \\ Hyun-Woo Kim ${ }^{1}$, Kwang-Jin $\mathrm{Oh}^{1}$, \\ Yun Tai $\mathrm{Kim}^{2}$, Sun-Mi Jung ${ }^{3}$ \\ and Seok Ho Cha ${ }^{1,4}$ \\ ${ }^{1}$ Department of Pharmacology and Toxicology \\ ${ }^{2}$ Department of Physiology and Biophysics \\ College of Medicine \\ ${ }^{3}$ Department of Biological Engineering \\ Inha University, Incheon, Korea \\ ${ }^{4}$ Corresponding author: Tel, 82-32-890-0957; \\ Fax, 82-32-890-0957; E-mail, shcha@inha.ac.kr
}

\section{Accepted 2 August 2005}

Abbreviations: $\left[\mathrm{Ca}^{2+}\right]$, intracellular calcium concentration; $\left[\mathrm{Ca}^{2+}\right]_{\mathrm{o}}$, extracellular calcium concentration; CaSR, calcium sensing receptor; MMC, mouse mesangial cells; PLC, phospholipase C

\begin{abstract}
The extracellular calcium sensing receptor (CaSR) belongs to the type III family of G-protein-coupled receptors, a family that comprises the metabotropic glutamate receptor and the putative vomeronasal organ receptors. The CaSR plays an important role for calcium homeostasis in parathyroid cells, kidney cells and other cells to directly 'sense' changes in the extracellular calcium ion concentration $\left(\left[\mathrm{Ca}^{2+}\right]_{0}\right)$. The mesangial cells are known to be involved in many pathologic sequences through the mediation of altered glomerular hemodynamics, cell proliferation, and matrix production. In this study, we examined the expression of the CaSR in the mouse mesangial cell lines (MMC, ATCC number CRL-1927). Reverse transcription- polymerase chain reaction (RT-PCR) was perform with CaSR-specific primers, and this was followed by nucleotide sequencing of the amplified product; this process identified the CaSR transcript in the MMCs. Moreover, CaSR protein was present in the MMCs as assessed by Western blot and immunocytochemical analysis using a polyclonal antibody specific for the CaSR. Functionally, $\left[\mathrm{Ca}^{2+}\right]_{0}$ induced the increment of the intracellular calcium concentration $\left(\left[\mathrm{Ca}^{2+}\right]_{i}\right)$ in a dose-dependent manner. This $\left[\mathrm{Ca}^{2+}\right]_{i}$ increment by $\left[\mathrm{Ca}^{2+}\right]$ 。 was attenuated by the pretreatment with a
\end{abstract}

phospholipase C inhibitor (U73122) and also by a pretreatment with a CaSR antagonist (NPS 2390). The similar results were also obtained in $\mathrm{IP}_{3}$ accumulation by $\left[\mathrm{Ca}^{2+}\right]_{0}$. To investigate the physiological effect of the CaSR, the effect of the $\left[\mathrm{Ca}^{2+}\right]_{\text {o on cell pro- }}$ liferation was studied. The increased $\left[\mathrm{Ca}^{2+}\right]_{0}$ (up to 10 $\mathrm{mM}$ ) produced a significant increase in the cell numbers. This mitogenic effect of $\left[\mathrm{Ca}^{2+}\right]_{0}$ was inhibited by the co-treatment with a CaSR antagonist. From these results, the $\left[\mathrm{Ca}^{2+}\right]_{0}$-induced $\left[\mathrm{Ca}^{2+}\right]_{i}$ eleva tion in the MMC is coupled with the extracellular calcium sensing receptor. Furthermore, $\left[\mathrm{Ca}^{2+}\right]_{0}$ pro duces a mitogenic effect in MMCs.

Keywords: calcium signaling; cell proliferation; glomerular mesangium; mice; receptors, calcium-sensing

\section{Introduction}

Serum calcium levels in healthy adults remain stable because the amount of calcium entering the extracellular compartment matches the amount excreted by the kidneys. This balance is mainly achieved by the calcium-sensing receptor (CaSR) that is located on the surface of the various types of cells (Houillier et al., 2003). In addition, extracellular calcium is essential for a number of vital processes, including bone mineralization, blood coagulation, regulation of enzymatic activity and the modulation of the permeability and excitability of the plasma membranes. For these reasons, the calcium concentration in the extracellular fluids is under strict control by a complex homeostatic system that includes the bones, kidney, intestines and the parathyroid and thyroid glands (Brown, 1991; Shin et al., 2003, Jung et al., 2005).

The extracellular CaSR is an essential component of this system for regulating the parathyroid hormone secretion and the $\mathrm{Ca}^{2+}$ excretion by the kidney. The CaSR belongs to the type III family of G-proteincoupled receptors that comprises the metabotropic glutamate receptor and the putative vomeronasal organ receptors (Brown et al., 1993).

In the kidney, experimental studies have suggested that CaSRs increase the intracellular calcium concentration and they regulate divalent mineral reabsorption, water reabsorption and urinary concentration (Riccardi et al., 1996, Arthur et al., 1997). 
These studies have also shown the distribution of CaSRs along the rat nephron. They showed the existence of the CaSR transcript using RT-PCR and the in situ hybridization technique. The CaSRs are localized at the glomeruli, the proximal convoluted tubule, the proximal straight tubule, the cortical thick ascending limb, the distal convoluted tubule and the cortical collecting duct (Brown et al., 1993; Riccardi et al., 1996; Caride et al., 1998). Although the physiological roles of CaSRs in the proximal convoluted tubule, the proximal straight tubule, the cortical thick ascending limb, the distal convoluted tubule and the cortical collecting duct are relatively well established (Riccardi et al., 1996; Desfleurs et al., 1998; Faurskov and Bjerregaard, 2002; Conigrave and Lok, 2004), the investigations on the signal transduction cascade and the physiological function of CaSR in the glomerulus have not been conducted.

The glomerulus is an important component of the nephron because renal filtration starts from this portion. The glomerulus is composed of several types of cells such as the endothelial cells, the mesangial cells, the epithelial cells and the podocytes. Among them, the mesangial cells play an important role for the regulation of glomerular filtration by contraction, for the secretion of structural elements and for the endocytosis of macromolecules including immune complexes (Mene et al., 1989). Therefore, understanding the functional role of the CaSRs in mesangial cells gives scientists additional information on the renal physiology of CaSRs.

The purpose of our current study is to clarify the expression and the physiological function of CaSRs by using molecular techniques and cell proliferation assay on the glomerular mesangial cell line.

\section{Materials and Methods}

\section{Materials}

The agents used in this study were purchased from the following sources: NPS 2390, Fura-2/ AM and TRI reagent from Sigma Chemical (St. Louis, Mo.); Dulbecco's modified Eagles Medium (DMEM), calcium free DMEM, penicillin-streptomycin and fetal bovine serum (FBS) from Gibco BRL (Grand Island, NY); ATP monitoring reagent from Bio Orbit, Turku, Finland; Reverse transcription-polymerase chain reaction related materials from TaKaRa Korea (Seoul, Korea); Polyclonal CaSR antibody from Affinity BioReagents (Deerfield, IL) and secondary antibodies from Jackson Immunoresearch (West Grove, PA). All other chemicals used were of the highest grade available.

\section{Cell culture}

The mouse mesangial cell line (MMC, CRL1927) was purchased from American Type Culture Collection and cultured in high glucose DMEM supplemented $10 \%$ heat-inactivated FBS, penicillin $(100 \mathrm{U} / \mathrm{ml})$ and streptomycin $(100 \mathrm{U} / \mathrm{ml})$. Cultures were maintained at $37^{\circ} \mathrm{C}$ in a $5 \% \mathrm{CO}_{2}$ humidified air.

\section{Total RNA isolation and RT-PCR analysis}

Extraction of total RNA was conducted by using the TRI reagent according to the manufacturer's instructions. Isolated total RNA (500 ng) was reverse transcribed using $5 \mathrm{U}$ of $\mathrm{AMV}$ reverse transcriptase $\mathrm{XL}$ for $30 \mathrm{~min}$. The prepared cDNAs were employed as template for PCR. The condition for PCR was as follows; one cycle of $1 \mathrm{~min}$ at $94^{\circ} \mathrm{C}, 35$ cycles each for $30 \mathrm{sec}$ at $94^{\circ} \mathrm{C}, 30 \mathrm{sec}$ at $55^{\circ} \mathrm{C}$ and $60 \mathrm{sec}$ at $72^{\circ} \mathrm{C}$, and one cycle of $10 \mathrm{~min}$ at $72^{\circ} \mathrm{C}$. The PCR products $(15 \mu \mathrm{l})$ were then separated on a $1 \%$ agarose gel by electrophoresis and stained with ethidium bromide (Cha et al., 2004). The primer sequences for CaSR were designed within coding region (sense 5'-TCA ACC TGC AGT TCC TGC TGG-3' and antisense 5'TGG CAT AGG CTG GAA TGA AGG-3'; product size $318 \mathrm{bp})$.

\section{Western blot analysis}

The MMCs were washed with cold phosphatebuffered saline (PBS, pH 7.4) and harvested. Subsequently, the cells were homogenized in 9 volumes of $0.3 \mathrm{M}$ sucrose, $0.26 \mathrm{U} / \mathrm{ml}$ aprotinin, $0.1 \mathrm{mM}$ phenylmethylsulfonyl fluoride, $10 \mu \mathrm{g} / \mathrm{ml}$ leupeptin, and 10 $\mu \mathrm{g} / \mathrm{ml}$ trypsin inhibitor, with 10 strokes of a motordriven Teflon/glass homogenizer. The homogenate was centrifuged for $5 \mathrm{~min}$ at $500 \times \mathrm{g}$, and the supernatant was centrifuged further for $10 \mathrm{~min}$ at $8,000 \times g$. The supernatant was centrifuged for 40 $\min$ at $100,000 \times g$, and the membrane pellet was resuspended in $0.25 \mathrm{M}$ sucrose, $100 \mathrm{mM} \mathrm{KCl}, 5 \mathrm{mM}$ $\mathrm{MgCl}_{2}$, and $50 \mathrm{mM}$ Tris ( $\mathrm{pH} 7.4$ ). The protein samples were heated at $100^{\circ} \mathrm{C}$ for $10 \mathrm{~min}$ in sample buffer and subjected to $10 \%$ SDS-polyacrylamide gel electrophoresis. The separated proteins were transferred electrically to a Hybond-P polyvinylidene difluoride transfer membrane (Amersham Pharmacia Biotech). This membrane was blocked with solution of $5 \%$ non-fat dried milk. Membrane was then incubated with CaSR antibody (1:200) for $1 \mathrm{~h}$ at room temperature and then incubated further with the horseradish peroxidase-conjugated secondary antibody (1:3000) for another $1 \mathrm{~h}$ at room temperature. After washing, the membrane was visualized by the ECL kit (Amersham Pharmacia Biotech. Buckinghamshire, UK). 


\section{Confocal microscopy}

The cultured MMCs on cover slips were fixed with 95\% ice-cold ethanol for $10 \mathrm{~min}$ at room temperature and permeabilized by $0.1 \%$ Triton $\mathrm{X}-100$ solution in PBS (10 min in room temperature). The nonspecific binding sites were blocked with $10 \%$ goat serum in PBS for $30 \mathrm{~min}$ in room temperature. Polyclonal CaSR antibody (1:100) was treated to the fixed cells for $1 \mathrm{~h}$ in room temperature. Secondary antibodies without prior antibody treatment were also included as controls. After washing, cells were stained with fluorescein isothiocyanate (FITC)-conjugated secondary antibodies for $30 \mathrm{~min}$. After washing, samples were examined appropriate-wavelength under a Bio-Rad MRC 1000 confocal microscope. More than 50 cells have been inspected per experiment and the photos of cells with typical morphology and staining are presented.

\section{Measurement of $\left[\mathrm{Ca}^{2+}\right]_{\mathrm{i}}$}

$\left[\mathrm{Ca}^{2+}\right]$ i was measured using the method previously described (Jung et al., 2005). Cells were harvested and seeded on to a $22 \times 22$ cover glass attached to a $1-\mathrm{cm}^{2}$ area at the bottom of $35-\mathrm{mm}$ plastic culture dishes at a concentration of $10^{4}$ cells/dish on the two days before conducting the experiment. Cells were then washed with modified Hanks' solution consisting of (in $\mathrm{mM}$ ): $\mathrm{NaCl}, 127 ; \mathrm{MgSO}_{4}, 0.8 ; \mathrm{KH}_{2} \mathrm{PO}_{4}$, 0.44; $\mathrm{NaHPO}_{4}, 0.33 ; \mathrm{MgCl}_{2}, 1$; HEPES, $10 ; \mathrm{CaCl}_{2}$, $0.5 ; \mathrm{pH} 7.4$; they were then loaded in Fura-2/AM (10 $\mu \mathrm{M})$ for $30 \mathrm{~min}$ at $37^{\circ} \mathrm{C}$. Fluorescence-loaded cells were washed three times with the same solution to exclude the unloaded Fura-2/AM. The fluorescence in MMCs was measured at room temperature using the $\mathrm{InCa}^{\mathrm{TM}}$ Imaging System (Intracellular Imaging Inc., Cincinnati, OH). The $\left[\mathrm{Ca}^{2+}\right]_{i}$ was calculated from a standard curve generated in situ.

\section{Measurement of $\mathrm{IP}_{3}$}

$\mathrm{IP}_{3}$ contents by extracellular calcium in MMC were determined using a radioimmunoassay kit (Amersham, UK). In brief, the MMCs in $0.5 \mathrm{mM}$ calcium and serum free DMEM were preincubated with $10 \mathrm{mM} \mathrm{LiCl}$ at $37^{\circ} \mathrm{C}$ for $10 \mathrm{~min}$. To analyze the $\mathrm{IP}_{3}$ production, the MMCs were incubated at $37^{\circ} \mathrm{C}$ for $20 \mathrm{~s}$ following their addition to the chemicals $\left(\mathrm{CaCl}_{2}\right.$, U73122 and CaSR antagonist). The reaction was terminated by the addition of $100 \%$ trichloroacetic acid (final concentration; $15 \% \mathrm{wt} / \mathrm{vol}$ ). After collecting the supernatant, $\mathrm{pH}$ was adjusted to 7.50 by titration. The aqueous layer was separated by centrifugation $(3,000 \times \mathrm{g})$ for $15 \mathrm{~min}$ at $4^{\circ} \mathrm{C}$. An aliquot $(100 \mu \mathrm{l})$ of supernatant was transferred to a scintillation vial (polypropylene, $12 \times 75 \mathrm{~mm}$ ) for quantita- tion of the $\mathrm{IP}_{3}$. The $\mathrm{IP}_{3}$ contents in the supernatant were determined using a radioimmunoassay kit (Amersham, UK) (Jung and Endou, 1990). Samples were normalized based on total protein using a BCA protein assay.

\section{Determination of cell proliferation}

Cells were seeded at a concentration of $5 \times 10^{3}$ cells/well to a 12-well plate and incubated for 1 day for cell attachment to the bottom. After confirmation of cell attachment, extracellular calcium varying concentrations (1,5 and $10 \mathrm{mM}$ ) and with/without CaSR antagonist (NPS 2390, $5 \mu \mathrm{M}$ ) were treated for 7 days. To determine cell proliferation, cells were detached using trypsin-EDTA solution $(0.25 \%)$ and the cell number was counted using trypan blue staining (Park et al., 2004).

\section{Determination of intracellular ATP content}

Intracellular ATP was measured with a microchemiluminescence method. After removing the supernatant, $1 \mathrm{ml}$ of $10 \%$ trichloroacetic acid was treated for extraction of cellular ATP. Then, $10 \mu \mathrm{l}$ of the extracted samples were transferred to polystyrene cuvettes filled with $160 \mu \mathrm{l}$ of $0.1 \mathrm{M}$ tris (hydroxymethyl)aminomethane/acetate buffer containing 0.5 mM EDTA ( $\mathrm{pH}$ 7.75). The cuvettes were set into a luminometer (TD-2020, Turner Designs, CA). After the addition of ATP-monitoring agent $(40 \mu \mathrm{l})$, the light intensity was measured.

\section{Statistical analysis}

Data obtained were expressed as the means \pm SE. Statistical analysis was performed using Student's $t$ test and ANOVA for two-group comparison and the comparison of multiple data, respectively. A $P$ value less than 0.05 is considered statistically significant.

\section{Results}

\section{Expression of CaSR mRNA and protein in MMCs}

In order to confirm the molecular appearance of CaSR mRNA and protein, RT-PCR and Western blot analysis were performed on the MMCs. As shown in Figure $1 \mathrm{~A}$, the designated PCR product (318 bp) was observed (Figure 1A). The identities of the PCR products were confirmed by nucleotide sequencing after they were subcloned into a TA-cloning vector (Invitrogen, data not shown). The CaSR protein (about $120 \mathrm{kDa}$ ) was also detected in the MMCs (Figure 1B). When the CaSR protein expression was confirmed by immunocytochemistry, the CaSR pro- 
A

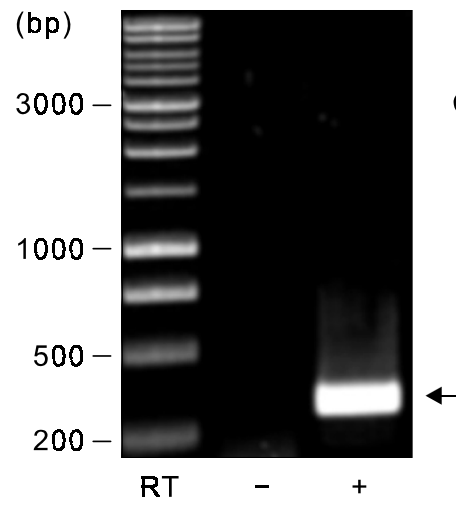

\section{C}

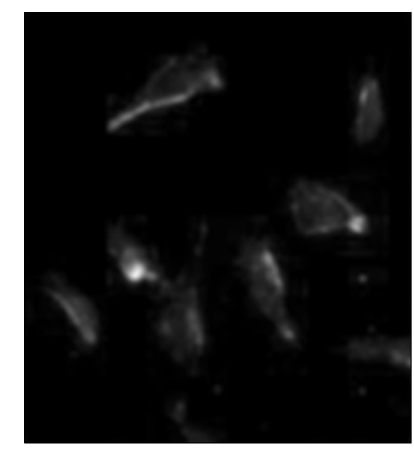

B

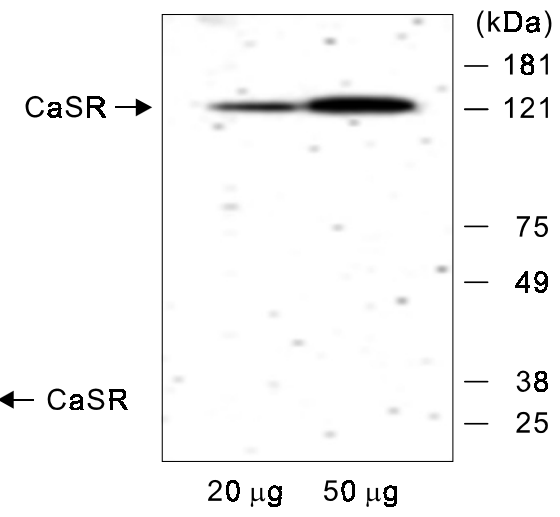

D

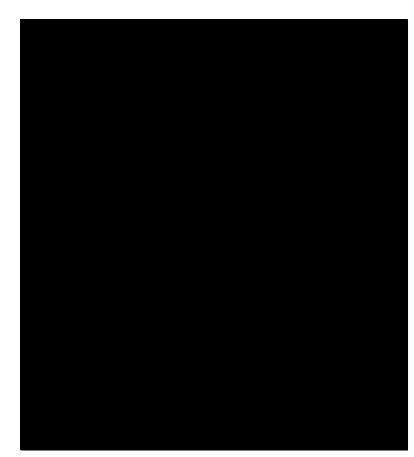

Figure 1. The mRNA and protein expression of CaSR in MMC. (A) Expression of CaSR mRNA was determined by employing RT-PCR (35 cycles). PCR products were separated on a $1 \%$ agarose gel and detected with ethidium bromide staining. (B) CaSR protein in MMCs detected by Western blot analysis. Isolated membrane proteins (20 and $50 \mu \mathrm{g} / \mathrm{lane}$ ) were separated by electrophoresis on a $10 \%$ acrylamide gel and presence of CaSR was detected with CaSR (1:200) antibody. Figures (A and B) represent the typical result from 3 independent experiments. (C) MMCs stained with CaSR antibody $(1: 100)$ immunocytochemically and detected using confocal microscopy. Cells were stained with FITC-conjugated secondary antibody. At least 50 cells were examined and the present images represent typical staining pattern for the majority of examined cells. (D) Stained only with secondary antibody without the prior treatment of CaSR antibody to show the images of non-specific bindings. tein was localized at the plasma membrane along with some cytoplasmic localization (Figure 1C). As shown in Figure 1D, any effect of the secondary antibody was not detected.

\section{Effects of extracellular calcium on the intracellular calcium mobilization and $\mathrm{IP}_{3}$ accumulation in the MMCs}

In order to determine the effects of $\left[\mathrm{Ca}^{2+}\right]_{0}$ on the MMCs, the $\left[\mathrm{Ca}^{2+}\right]_{0}$-induced $\left[\mathrm{Ca}^{2+}\right]_{i}$ increases were monitored. The basal $\left[\mathrm{Ca}^{2+}\right]_{\mathrm{i}}$, as measured in the bathing solution that contained $0.5 \mathrm{mM} \mathrm{CaCl}_{2}$, was $57 \pm 6 \mathrm{nM}(n=60)$. As shown in Figure 2, the increase in the $\left[\mathrm{Ca}^{2+}\right]_{\text {i }}$ due to the $\left[\mathrm{Ca}^{2+}\right]_{0}$ occurred in a concentration-dependent manner, and a significant effect was observed when the concentration of $\left[\mathrm{Ca}^{2+}\right]_{0}$ was higher than $2.5 \mathrm{mM}$. The peak elevation in $\left[\mathrm{Ca}^{2+}\right]_{\mathrm{i}}(196 \pm 6 \mathrm{nM})$ was achieved when the MMCs were stimulated with $20 \mathrm{mM}$ of $\left[\mathrm{Ca}^{2+}\right]_{0}$. The half maximal effective concentration of $\left[\mathrm{Ca}^{2+}\right]_{0}$ that was necessary to achieve the $\left[\mathrm{Ca}^{2+}\right]_{i}$ response in the MMC was about $7.2 \mathrm{mM}$.

The $\left[\mathrm{Ca}^{2+}\right]_{0}(10 \mathrm{mM})$-induced $\left[\mathrm{Ca}^{2+}\right]_{\mathrm{i}}$ increment was attenuated in a concentration dependent manner by a 2 min pretreatment with NPS $2390(5 \mu \mathrm{M}, 32.3 \pm$
$5.0 \mathrm{nM} ; 10 \mu \mathrm{M}, 10.1 \pm 4.6 \mathrm{nM}$ vs. $10 \mathrm{mM} \mathrm{Ca}, 83.0$ $\pm 9.8 \mathrm{nM}$ ), an antagonist of CaSR (Figure $3 \mathrm{~A}$ and $B)$. To evaluate the possible involvement of phospholipase $\mathrm{C}$ in the $\left[\mathrm{Ca}^{2+}\right]_{0}$-induced $\left[\mathrm{Ca}^{2+}\right]_{i}$ increase, the effect of U73122 on the $\left[\mathrm{Ca}^{2+}\right]_{0}$-induced cytosolic free calcium mobilization was investigated. As shown in Figure $3 C$ and $D$, the net transient $\left[\mathrm{Ca}^{2+}\right]_{\mathrm{i}}$ increase from the $\left[\mathrm{Ca}^{2+}\right]_{0}$ was significantly inhibited by a 20-min pretreatment with $1 \mu \mathrm{M}$ of $\mathrm{U} 73122$ $\left(\left[\mathrm{Ca}^{2+}\right]_{0}\right.$-treated: $75 \pm 7.2 \mathrm{nM}$ and U73122-treated: $12.0 \pm 5.7 \mathrm{nM})$. To determine the relationship between $\left[\mathrm{Ca}^{2+}\right]_{\mathrm{i}}$ increase and $\mathrm{IP}_{3}$ production, we measured $\left[\mathrm{Ca}^{2+}\right]_{0}$-induced $\mathrm{IP}_{3}$ production and effects of U73122 and CaSR antagonist on $\left[\mathrm{Ca}^{2+}\right]_{0}$-induced $\mathrm{IP}_{3}$ production. When the extracellular calcium $(10 \mathrm{mM}$ for $20 \mathrm{~s}$ ) was treated to MMCs, $\mathrm{IP}_{3}$ accumulation was $2.6 \pm 0.4$ times of basal levels $(n=3, P<$ $0.05)$. As shown in Figure $3 \mathrm{E}$, this extracellular calcium-stimulated $\mathrm{IP}_{3}$ elevation was significantly inhibited by the pretreatment with U73122 (1 $\mu \mathrm{M}$ for 20 min; $1.3 \pm 0.2$ times of basal level) and NPS 2390 (10 $\mu \mathrm{M}$ for $2 \mathrm{~min}, 1.1 \pm 0.4$ times of basal level). The single effect of U73122 and NPS 2390 was negligible (data not shown). 

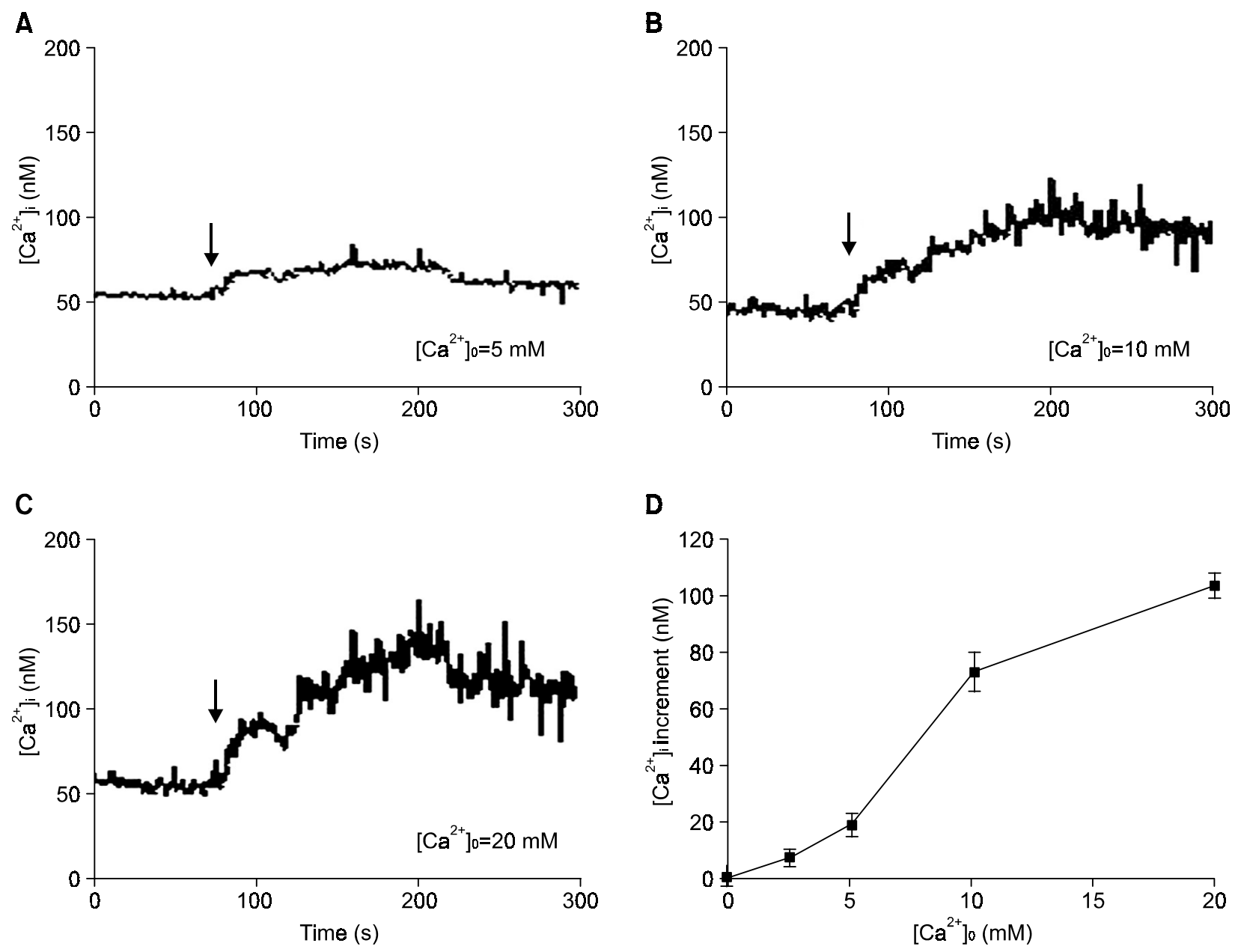

Figure 2. Dose-response curve of peak values in $\left[\mathrm{Ca}^{2+}\right]_{i}$ evoked transiently as a function of $\left[\mathrm{Ca}^{2+}\right]_{0}$ concentrations in MMCs. Fura-2 AM-loaded cells were placed in a $0.5 \mathrm{mM} \mathrm{CaCl}_{2}$ containing Hanks' solution. Each of $\left[\mathrm{Ca}^{2+}\right]_{0}$-containing solution was applied by changing of solution (flow rate $3 \mathrm{ml} / \mathrm{min}$ ). The typical signalings represented (A) to (C). The line graph represents the differences of $\left[\mathrm{Ca}^{2+}\right]$ from basal level to peak values (D). Result was from 3-4 independent experiments and each experiment measured at least 10-15 cells. Values are represented as mean \pm SE.

\section{Effects of extracellular calcium on MMC proliferation}

To investigate the physiological role of CaSR, the effect of $\left[\mathrm{Ca}^{2+}\right]_{0}$ on the cell proliferation was studied. Elevating the $\left[\mathrm{Ca}^{2+}\right]_{0}$ from 1 to $5 \mathrm{mM}$ was sufficient to elicit proliferation after a chronic treatment of at least 5 days. The percent increments of the cell proliferation were $16.7 \%$ and $37.5 \%$, as compared with the control $\left(\left[\mathrm{Ca}^{2+}\right]_{0}=1 \mathrm{mM}\right)$ at 5 days and 7 days, respectively (Figure $4 \mathrm{~A})$. This increment by $\left[\mathrm{Ca}^{2+}\right]_{0}$ was significantly inhibited by the co-treatment with the antagonist of CaSR (NPS 2390, $5 \mu \mathrm{M}$ ). There was no single effect for NPS 2390. This increment of cell proliferation was also confirmed by determining the cellular contents of ATP (Figure 4B). The high concentration of $\left[\mathrm{Ca}^{2+}\right]_{0}(10 \mathrm{mM})$ did not affect cell viability (Figure 4B).

\section{Discussion}

The results obtained in the current study demonstrate for the first time that the extracellular calcium sensing receptor (CaSR) is expressed in the renal glomerular mesangial cells, and CaSRs play an important role in cell proliferation. Several lines of evidences that are provided in the present study support this conclusion. (1) The RT-PCR results, the immunoblot analysis and the immunocytochemical results indicated that CaSRs are expressed in the cultured mouse mesangial cell line. (2) The extracellular calcium increased the intracellular free calcium concentration in a concentration-dependent manner. (3) The extracellular calcium enhanced cell proliferation via the CaSRs.

Extracellular calcium is essential to a number of processes throughout the body, including blood 
A

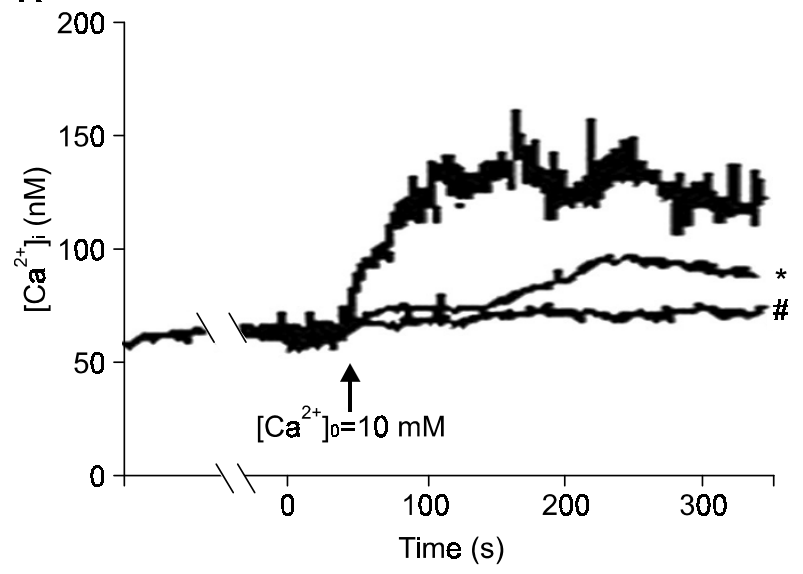

C

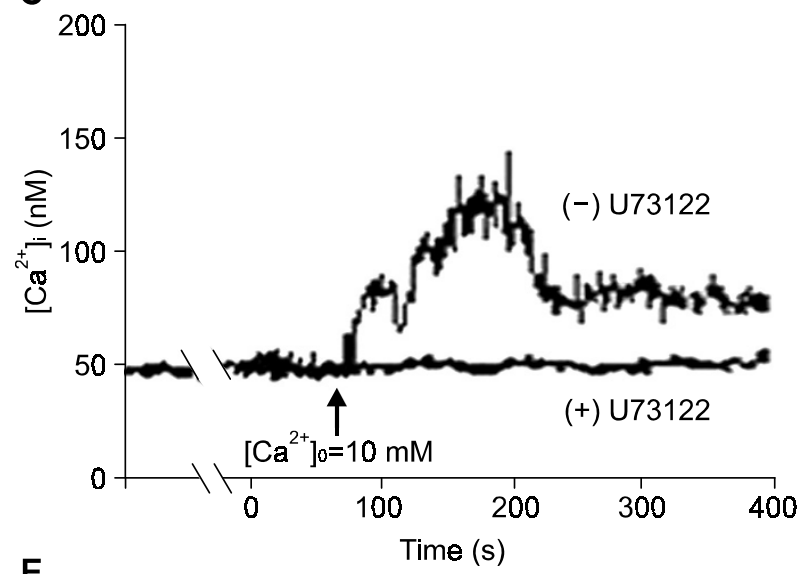

E

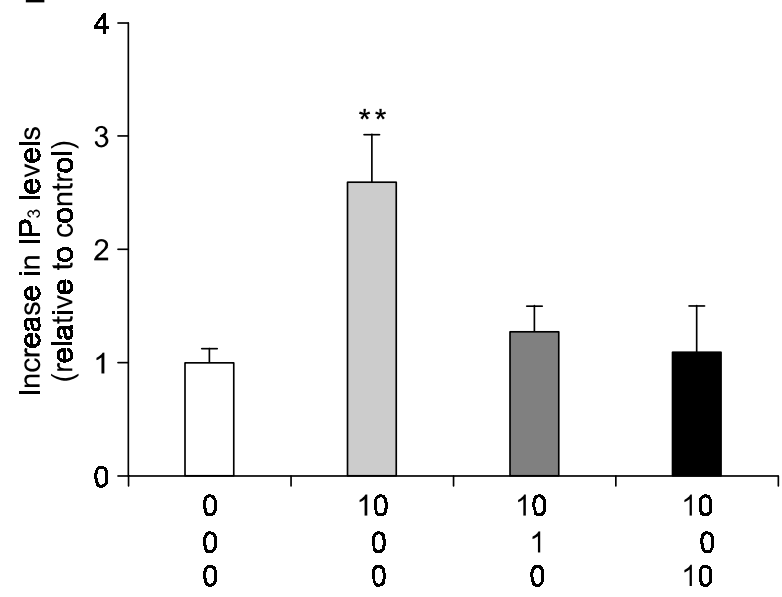

B

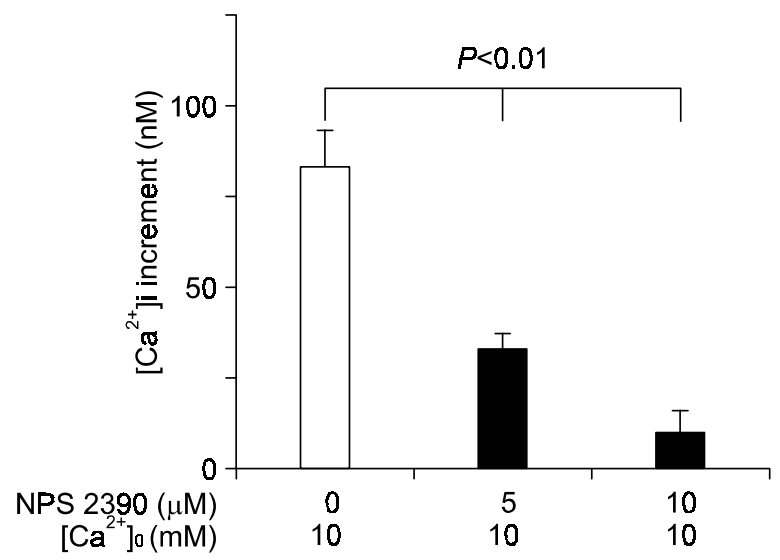

D

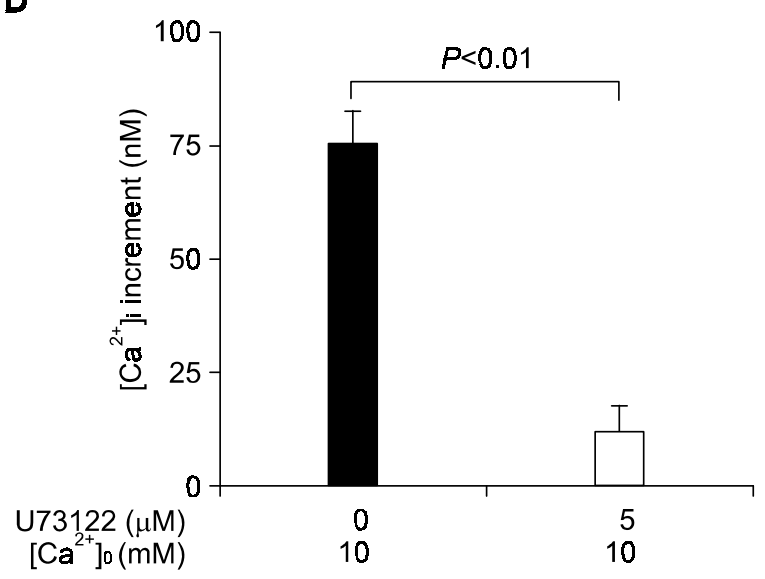

$\left[\mathrm{Ca}^{2+}\right]_{0}(\mathrm{mM})$
$\mathrm{U} 73122(\mu \mathrm{M})$

NPS $2390(\mu \mathrm{M})$

Figure 3. Characterization of the effect of $\left[\mathrm{Ca}^{2+}\right]_{0}$ on the elevation of $\left[\mathrm{Ca}^{2+}\right]_{i}$ in MMCs. The $\left[\mathrm{Ca}^{2+}\right]_{i}$ was measured in $0.5 \mathrm{mM} \mathrm{basal}\left[\mathrm{Ca}^{2+}\right]_{0}$. $\left[\mathrm{Ca}^{2+}\right]_{i}$ was measured in Fura-2-loaded MMCs as described in Materials and Methods. The NPS 2390 ( $^{*}, 5 \mu \mathrm{M}$ and ${ }^{\#}, 10 \mu \mathrm{M}$, respectively) was pretreated for 2 min and subsequently treated $\left[\mathrm{Ca}^{2+}\right]_{0}$ in MMCs. The typical signalings (A) and increments of peak values (B) were summarized. The $1 \mu M$ of U73122 was pretreated for $20 \mathrm{~min}$ and subsequently treated $\left[\mathrm{Ca}^{2+}\right]_{0}(10 \mathrm{mM})$. The typical signalings and increments of peak values were also summarized in $(C)$ and (D). Result was from 3-4 independent experiments and each experiment measured at least 10-15 cells. Values are represented as means \pm SE. Effects of U73122 or NPS 2390 on $\left[\mathrm{Ca}^{2+}\right]_{0}(10 \mathrm{mM})$-induced $\mathrm{IP}_{3}$ accumulation. $\mathrm{IP}_{3}$ was detected by radio immunoassay $(\mathrm{E})$. Results were represented mean \pm s.e. from 3 independent experiments. 
A

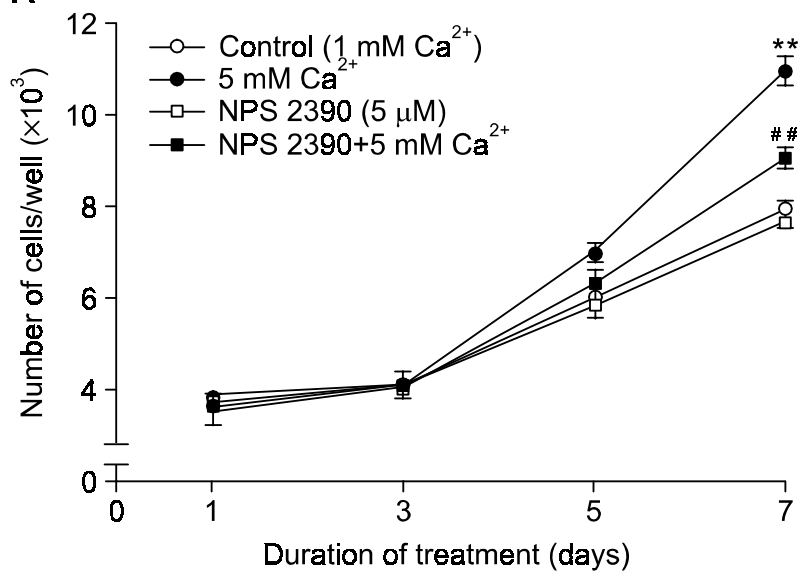

B

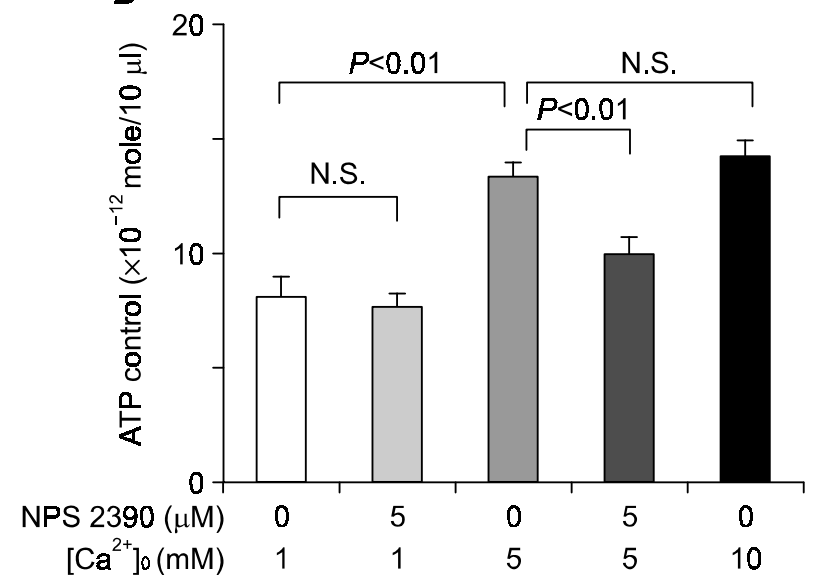

Figure 4. The effect of $\left[\mathrm{Ca}^{2+}\right]_{0}$ in mesangial cell proliferation. (A) Cell growth curves of MMCs following the treatment of $5 \mathrm{mM}\left[\mathrm{Ca}^{2+}\right]_{0}$ with/without NPS $2390(5 \mu \mathrm{M})$. Cells were seeded at a concentration of $5 \times 10^{3}$ cells/well to a 12-well plate and incubated for 1 day for cell attachment to the bottom. Cells were counted after detaching using trypsin-EDTA. ${ }^{*} P<0.05,{ }^{* *} P<0.01$ versus control and ${ }^{\# \#} P<0.01$ versus $5 \mathrm{mM}\left[\mathrm{Ca}{ }^{2+}\right]$ 。 group. (B) Quantitative evaluation was performed at the 7 day using measurement of intracellular ATP contents as described in Materials and Methods. All wells, in triplicate, were solubilized with $1 \%$ trichloroacetic acid and the ATP content was determined. The results are represented as means \pm SE in triplicate from 3 different experiments.

coagulation, bone mineralization, enzymatic regulation and control of the permeability and excitability of the plasma membranes. The levels of serum calcium remain stable in healthy adults because the amount of calcium entering the extracellular compartment matches the amount excreted through the kidneys. The narrow range of the extracellular calcium concentration is largely regulated by parathyroid hormone (PTH). In addition, the calcium sensing receptor (CaSR) also contributes to the regulation of the serum calcium concentration (Drueke, 2004).

Hypercalcemia has been shown to occur in primary hyperparathyroidism, malignancy and less frequently, in hypervitaminosis D or sarcoidosis (Wrong, 1998), and renal injury is often seen with hypercalcemia. In the kidney, hypercalcemia can alter many aspect of renal function, including reducing the glomerular filtration rate (Porter et al., 1999) and increasing renal vasoconstriction (Fynn et al., 1977). There have been a numerous reports on the roles of the CaSRs in the kidney. Riccardi and coworkers (Riccardi et al., 1996) have shown the localization of CaSRs along the rat nephron. This result well agrees with the reported physiological roles for CaSRs in the nephron segments. They also showed that CaSRs are localized in the glomerulus. Unfortunately, there have been no reports on the roles of CaSRs in the glomerulus. Therefore, we investigated the role of CaSRs in the mesangial cells. Mesangial cells respond to a variety of vasoactive agents such as angiotensin II, vasopressin, leukotrienes, platelet activating factor and so forth (Ausiello et al.,
1980; Kreisberg et al., 1985; Schlondorff, 1987). The mesangial cells are also known to be involved in many pathologic sequences through the mediation of altered glomerular hemodynamics, cell proliferation, and matrix production (Mauer, 1994; Lee et al., 2000).

In the first step of our current study, we performed RT-PCR, Western blot analysis and immunocytochemistry for confirmation of the CaSR expression in the cultured mouse mesangial cell lines (MMC). The result of this experiment well demonstrated the expression of CaSRs. The major portion of the CaSR protein was localized in the plasma membrane with the cytoplasmic expression in the MMC (Figure 1). The glomerulus is composed of several cell types such as endothelial cells outlining the glomerular capillaries, mesangial cells functioning as pericytes adjacent to the glomerular capillary, and visceral glomerular epithelial cells or podocytes attached to the glomerular epithelial cells covering the inner surface of the Bowman's capsule (Remuzzi and Bertani, 1998), and so additional experiments that will demonstrate the existence of CaSRs in other glomerular endothelial and epithelial cells will be necessary.

In order to characterize the signaling mechanism of the CaSRs, the extracellular $\mathrm{Ca}^{2+}\left(\left[\mathrm{Ca}^{2+}\right]_{0}\right)$ induced intracellular free calcium $\left(\left[\mathrm{Ca}^{2+}\right]_{i}\right)$ mobilization was studied. Henegar et al. (Henegar et al., 2003) reported the two cases of glomerular calcification in hypercalcemic nephropathy. In these patients serum calcium concentrations were $4.6 \mathrm{mM}$ and $5.0 \mathrm{mM}$, respectively. In other case, dramatic millimorar el- 
evations of extracellular calcium (as much as 40 $\mathrm{mM}$ ) are generated near the resorption sites as osteoclasts dissolve the mineralized matrix (Silver et al., 1988). Therefore, typical response pattern to $\left[\mathrm{Ca}^{2+}\right]_{0}$ and concentration dependency were investigated at $10 \mathrm{mM}$ and up to $20 \mathrm{mM}$ of $\left[\mathrm{Ca}^{2+}\right]_{0}$. The CaSR mediated $\left[\mathrm{Ca}^{2+}\right]_{i}$ increase was biphasic, and it was composed of an initial rapid increase and then a sustained increase. The high concentration of the extracellular $\mathrm{Ca}^{2+}$ increased the $\left[\mathrm{Ca}^{2+}\right]_{i}$ in a dosedependent manner. In the current experiment, the half-maximal effective concentration of $\left[\mathrm{Ca}^{2+}\right]_{0}$ necessary to achieve the $\left[\mathrm{Ca}^{2+}\right]_{i}$ responses in the MMCs was about $7.2 \mathrm{mM}$ (Figure 2). This value showed to be slightly higher than the previously reported values. Bai et al. (Bai et al.,1998) and Godwin (Godwin and Soltoff, 2002) demonstrated values of 4.0 $\mathrm{mM}$ in the CaSR transfected kidney cells and 4.6 $\mathrm{mM}$ in the MC3T3-E1 osteoblasts, respectively.

To further characterize the signaling mechanism of the CaSRs, we treated the MMCs with U73122, an inhibitor that disrupts the catalytic activity of phospholipase C (PLC). The pretreatment with U73122 inhibited the $\left[\mathrm{Ca}^{2+}\right]_{0}$-stimulated $\left[\mathrm{Ca}^{2+}\right]_{\mathrm{i}}$ increase. This result showed that the CaSR-mediated $\left[\mathrm{Ca}^{2+}\right]_{i}$ increase was related with the PLC. This revealed that the $\left[\mathrm{Ca}^{2+}\right]_{i}$ measuring system worked well and the $\left[\mathrm{Ca}^{2+}\right]_{\mathrm{i}}$ increment by $\left[\mathrm{Ca}^{2+}\right]_{0}$ was mediated by CaSR. As shown in Figure $3 \mathrm{C}$ and $\mathrm{E}$, this result was also confirmed by using NPS 2390, an antagonist of CaSR (Jung et al., 2005).

There are numerous reports showing the CaSRs' effect on cell proliferation in many cell types including myeloma (Yamaguchi et al., 2002), ovarian surface epithelial cells (Hobson et al., 2000), fibroblasts (McNeil et al., 1998) and osteoblasts (Dvorak et al., 2004). We also studied the CaSRstimulated mesangial proliferation (Figure 4A). Extracellular calcium ( $5 \mathrm{mM}$ ) stimulated the mesangial cell proliferation and this was inhibited by the cotreatment with a CaSR antagonist (NPS 2390, 5 $\mu \mathrm{M})$. The higher concentration of extracellular calcium $(10 \mathrm{mM})$ did not affect cell viability. Thus, the current findings that the CaSR activation evokes a mitogenic effect on the MMCs further support the notion that the CaSR is involved in this physiological process in a variety of cell types. Elevated CaSR expression may contribute to the action of growth signaling pathways, including mitogen-activated protein kinase (McNeil et al., 1998; Yamaguchi et al., 2002). In addition, many reports have shown that several protein kinases affect the CaSR-induced signaling cascades (Awata et al., 2001; Sakwe et al., 2004). Therefore, extensive investigations on the relationship between protein kinase and the CaSRs in MMCs will be necessary.
Mesangial cell proliferation is also thought to play an important role in glomerular injury, and mesangial cells may modulate the glomerular filtration rate by altering the surface area and/or the glomerular blood flow (Schlondorff, 1987). Investigating the role of CaSRs in mesangial cell proliferation is important for understanding the clinical pathophysiology of renal diseases. In conclusion, this study is the first to report that extracellular calcium-induced cytosolic free calcium mobilization in MMCs occurs via the calcium sensing receptor-mediated responses. In addition, the CaSR appears to display mitogenic activity.

\section{Acknowledgement}

This work was supported by Inha University Research Grant.

\section{References}

Arthur JM, Collinsworth GP, Gettys TW, Quarles LD, Raymond JR. Specific coupling of a cation-sensing receptor to $\mathrm{G}$ protein alpha-subunits in MDCK cells. Am J Physiol 1997;273:F129-35

Ausiello DA, Kreisberg JI, Roy C, Karnovsky MJ. Contraction of cultured rat glomerular cells of apparent mesangial origin after stimulation with angiotensin II and arginine vasopressin. J Clin Invest 1980;65:754-60

Awata H, Huang C, Handlogten ME, Miller RT. Interaction of the calcium-sensing receptor and filamin, a potential scaffolding protein. J Biol Chem 2001;276:34871-9

Bai M, Trivedi S, Lane CR, Yang Y, Quinn SJ, Brown EM. Protein kinase $C$ phosphorylation of threonine at position 888 in $\mathrm{Ca}^{2+}{ }_{0}$-sensing receptor $(\mathrm{CaR})$ inhibits coupling to $\mathrm{Ca}^{2+}$ store release. J Biol Chem 1998;273:21267-75

Brown EM. Extracellular $\mathrm{Ca}^{2+}$-sensing, regulation of parathyroid cell function and role of $\mathrm{Ca}^{2+}$ and other ions as extracellular (first) messengers. Physiol Rev 1991;71:371411

Brown EM, Gamba G, Riccardi D, Lombardi M, Butters R, Kifor O, Sun A, Hediger MA, Lytton J, Hebert SC. Cloning and characterization of an extracellular $\left(\mathrm{Ca}^{2+}\right)$ sensing receptor from bovine parathyroid gland. Nature 1993;366: $575-80$

Caride AJ, Chini EN, Homma S, Dousa TP, Penniston JT. mRNAs coding for the calcium-sensing receptor along the rat nephron: effect of a low-phosphate diet. Kidney Blood Press Res 1998;21:305-9

Cha SH, Shin SY, Jung SY, Kim YT, Park YJ, Kwak JO, Kim $\mathrm{HW}$, Suh CK. Evidence for $\mathrm{Na}^{+} / \mathrm{Ca}^{2+}$ Exchanger 1 association with caveolin-1 and -2 in C6 glioma cells. IUBMB Life 2004;56:621-7

Conigrave AD, Lok HC. Activation of renal calcium and water excretion by novel physiological and pharmacological activators of the calcium-sensing receptor. Clin Exp Pharmacol 
Physiol 2004;31:368-71

Desfleurs E, Wittner M, Simeone S, Pajaud S, Moine G, Rajerison R, Di Stefano A. Calcium-sensing receptor: regulation of electrolyte transport in the thick ascending limb of Henle's loop. Kidney Blood Press Res 1998;21:401-12

Drueke TB. Modulation and action of the calcium-sensing receptor. Nephrol Dial Transplant 2004;19:20-6

Dvorak MM, Siddiqua A, Ward DT, Howard Carter D, Dallas $S$, Nemeth EF, Riccardi D. Physiological changes in extracellular calcium concentration directly control osteoblast function in the absence of calciotropic hormones. Proc Natl Acad Sci U S A 2004;101:5140-5

Faurskov B, Bjerregaard HF. Evidence for cadmium mobilization of intracellular calcium through a divalent cation receptor in renal distal epithelial A6 cells. Pflugers Arch 2002;445:40-50

Fynn M, Onomakpome N, Peart WS. The effects of ionophores (A23187 and RO2-2985) on renin secretion and renal vasoconstriction. Proc R Soc Lond B Biol Sci 1977;199:199212

Godwin SL, Soltoff SP. Calcium-sensing receptor-mediated activation of phospholipase $\mathrm{C}-\gamma 1$ is downstream of phospholipase $C-\beta$ and protein kinase $C$ in MC3T3-E1 osteoblasts. Bone 2002;30:559-66

Henegar JR, Coleman JP, Cespedes J, Hughson MD. Glomerular calcification in hypercalcemic nephropathy. Arch Pathol Lab Med 2003;127:E80-5

Hobson SA, NcNeil SE, Lee F, Rodland KD. Signal transduction mechanisms linking increased extracellular calcium to proliferation in ovarian surface epithelial cells. Exp Cell Res 2000;258:1-11

Houillier P, Nicolet-Barousse L, Maruani G, Paillard M. What keeps serum calcium levels stabe? Joint Bone Spine 2003;70:407-13

Jung $\mathrm{KY}$, Endou $\mathrm{H}$. Mercury chloride as a possible phospholipase $\mathrm{C}$ activator: effect on angiotensin-Il-induced $\left[\mathrm{Ca}^{2+}\right]_{i}$ transient in the rat early proximal tubule. Biochem Biophys Res Commun 1990;173: 606-13

Jung SY, Kwak JO, Kim HW, Kim DS, Ryu SD, Ko CB, Cha $\mathrm{SH}$. Calcium sensing receptor forms complex with and up-regulated by caveolin-1 in cultured human osteosarcoma (Saos-2) cells. Exp Mol Med 2005;37:91-100

Kreisberg JI, Venkatachalam M, Troyer D. Contractile properties of cultured glomerular mesangial cells. Am J Physiol 1985;249:457-63

Lee HB, Ha H, Kim SI, Ziyadeh FN. Diabetic kidney disease research: Where do we stand at the trun of the centrury? Kidney Int Suppl 2000;77:1-2
Mauer SM. Structural-functional correlations of diabetic nephopathy. Kidney Int 1994;45:612-22

McNeil SE, Hobson SA, Nipper V, Rodland KD. Functional calcium-sensing receptors in rat fibroblasts are required for activation of SRC kinase and mitogen-activated protein kinase in response to extracellular calcium. J Biol Chem 1998;273:1114-20

Mene P, Simonson MS, Dunn MJ. Physiology of the mesangial cell. Physiol Rev 1989;69:1347-424

Park SW, Bae JS, Kim KS, Park SH, Lee BH, Choi JY, Park JY, Ha SW, Kim YL, Kwon TH, Kim IS, Park RW. Beta ig-h3 promotes renal proximal tubular epithelial cell adhesion, migration and proliferation through the interaction with $\alpha 3 \beta 1$ integrin. Exp Mol Med 2004;36:211-9

Porter L, Conlin PR, Scott J, Brown EM, El-Hajj Fuleihan G. Calcium modulation of the renin-aldosterone axis. J Endocrinol Invest 1999;22:115-21

Remuzzi G, Bertani T. Pathophysiology of progressive nephropathies. N Engl J Med 1998;339:1448-56

Riccardi D, Lee WS, Lee K, Segre GV, Brown EM, Hebert $\mathrm{SC}$. Localization of the extracellular $\mathrm{Ca}^{2+}$-sensing receptor and PTH/PTHrP receptor in rat kidney. Am J Physiol 1996;271:F951-6

Sakwe AM, Larsson M, Rask L. Involvement of protein kinase C-alpha and -epsilon in extracellular $\mathrm{Ca}^{2+}$ signalling mediated by the calcium sensing receptor. Exp Cell Res 2004;297:560-73

Schlondorff D. Roles of mesangium in glomerular function. Kidney Int 1996;49:1583-5

Schlondorff D. The glomerular mesangial cell: an expanding role for a specialized pericyte. FASEB J 1987;1:272-81

Shin MM, Kim YH, Kim SN, Kim GS, Baek JH. High extracellular $\mathrm{Ca}^{2+}$ alone stimulates osteoclast formation but inhibits in the presence of other osteoclastogenic factors. Exp Mol Med 2003;35:167-74

Silver IA, Murrills RJ, Etherington DJ. Microelectrode studies on the acid microenvironment beneath adherent macrophages and osteoclasts. Exp Cell Res 1988;175:559-66

Wrong O. Nephrocalcinosis. In Oxford Textbook of Clinical Nephrology (Davison AM, Cameron JS, Greenfeld JP, Kerr DNS, Rits E, Winearls CG, eds), 2nd ed, 1998, 1375-96, Oxford University Press, New York, NY

Yamaguchi T, Yamauchi M, Sugioto T, Chauhan D, Anderson $\mathrm{KC}$, Brown EM, Chihara K. The extracellular calcium $\left(\mathrm{Ca}_{\circ}{ }^{2+}\right)-$ sensing receptor is expressed in myeloma cells and modulates cell proliferation. Biochem Biophys Res Commun 2002; 299:532-8 